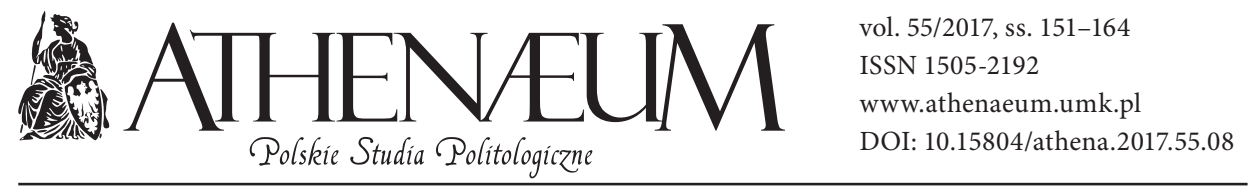

\title{
KSZTAŁTOWANIE BRYTYJSKIEGO SYSTEMU IMPERIALNEGO W ZATOCE PERSKIEJ PO ZAKOŃCZENIU I WOJNY ŚWIATOWEJ
}

\author{
SHAPING OF THE BRITISH IMPERIAL SYSTEM \\ IN THE PERSIAN GULF AFTER THE END OF WWI
}

Radosław Bania*

\begin{abstract}
ABSTRAKT
Począwszy od połowy XVIII wieku Imperium Brytyjskie było zaangażowane w budowanie silnej pozycji mocarstwowej w obszarze Zatoki Perskiej. Obszar ten był traktowany jako istotny dla zabezpieczenia morskich szlaków komunikacyjnych pomiędzy metropolią a Indiami Brytyjskimi. W XIX wieku Wielka Brytania zdołała w oparciu o tzw. traktaty na wyłączność uzależnić od siebie arabskie szejkanaty Zatoki, obejmując je nieformalnym protektoratem. Rola Zatoki Perskiej dla Imperium Brytyjskiego wzrosła w przededniu wybuchu I wojny światowej, z uwagi na znaczenie znajdujących się tam zasobów ropy naftowej dla Royal Navy. Zakończenie I wojny światowej i objęcie przez Wielką Brytanię pozycji dominującego mocarstwa na Bliskim Wschodzie wymusiło konieczność opracowania nowych zasad polityki imperialnej wobec tego obszaru. Wypracowanie zasad tej polityki zostało zakończone pod koniec lat 20. XX wieku. Przyjęte wtedy rozwiązania określały
\end{abstract}

The British Empire had tried to build its dominant position in the Persian Gulf from the second half of the $18^{\text {th }}$ century. The region was seen as a key position for the security of the naval routs between Great Britain and the Indian Sub-Continent. During the $19^{\text {th }}$ century, the British Empire managed, using the so-called Exclusive Treaties, to cease its control over the Arab sheikdoms of the Gulf. The Gulf's significance for the British Empire has risen in the eve of the Great War. After the end of WWI, Great Britain became a dominant power in the Middle East. This situation forced the British Empire to establish new rules of the political and imperial engagement in the Middle East. This process was finished in the end of the 1920s. The rules of the imperial policy towards this region that had been established that time were executed till the end of the 1940s.

* Uniwersytet Łódzki, Katedra Bliskiego Wschodu i Północnej Afryki. 
podstawy brytyjskiej polityki wobec subregionu Zatoki do końca lat 40. XX wieku.
Keywords: British Empire, Persian Gulf, Imperial Policy

Słowa kluczowe: Imperium Brytyjskie, Zatoka Perska, polityka imperialna

Splot wydarzeń politycznych związanych zarówno z rozwojem wewnętrznej sytuacji politycznej na Półwyspie Arabskim, jak i rywalizacji międzynarodowej zdecydował o tym, że pod koniec XIX wieku Wielka Brytania umocniła swoją pozycję mocarstwową w północnym obszarze Zatoki Perskiej. W 1899 roku władca Kuwejtu książę Mubarak as-Sabah, obawiając się podporządkowania politycznego Turcji, zdecydował się na szukanie protekcji brytyjskiej. 23 stycznia zawarł on z przedstawicielem brytyjskim tzw. układ na wyłączność (Exclusive Treaty), w którym w zamian za brytyjską ochronę władca gwarantował, że żadna część jego kraju nie zostanie odstąpiona lub odsprzedana państwu trzeciemu bez zgody władz brytyjskich. Układ brytyjsko-kuwejcki z 1899 roku rozpoczynał okres zależności Kuwejtu od Imperium Brytyjskiego. Ta zaś uległa z początkiem $\mathrm{XX}$ wieku dalszemu umocnieniu. Jednym z najważniejszych wydarzeń określających stan relacji brytyjsko-kuwejckich, w 1904 roku nastąpiło utworzenie w Kuwejcie bezpośredniego przedstawicielstwa politycznego Wielkiej Brytanii w postaci brytyjskiej agencji politycznej. Do jej obowiązków miało należeć rozwijanie i utrzymywanie stosunków z Mubarakiem, sprzyjanie rozwojowi handlu brytyjskiego w północnym obszarze Zatoki Perskiej oraz obserwowanie działalności Turcji i innych mocarstw w sąsiedztwie Kuwejtu i w centralnej Arabii (Zdanowski, 2004, s. 113). Tym samym objęcie Kuwejtu brytyjskim protektoratem kończyło proces włączania arabskiego wybrzeża Zatoki w system zależności imperialnej, którą Wielka Brytania tworzyła w subregionie Zatoki Perskiej od polowy XVIII wieku. Zgodnie z tzw. doktryną Landsdowna obszar ten stawał się dla Imperium Brytyjskiego kluczowy dla zabezpieczenia szlaków komunikacyjnych z Indiami Brytyjskimi. Zakończenie I wojny światowej, w wyniku której Wielka Brytania stała się dominującym mocarstwem w regionie Zatoki Perskiej, przyniosło ze sobą nowe wyzwania, które wymagały ponownego określenia brytyjskiej polityki imperialnej w Zatoce. Niniejsze opracowanie poświęcone będzie analizie uwarunkowań, które doprowadziły do zdefiniowania roli i miejsca subregionu Zatoki Perskiej w polityce bliskowschodniej Imperium Brytyjskiego w okresie dwudziestolecia międzywojennego. 
Brytyjski system zależności imperialnych w Zatoce Perskiej ukształtował się w oparciu o rozwiązania polityczne tworzone uprzednio przez operującą w tej części Bliskiego Wschodu brytyjską Kompanię Wschodnioindyjską (East India Company). W 1763 roku Kompania zawarła z szejkiem Buszahry układ, w którego wyniku została tam utworzona faktoria handlowa (Zdanowski, 2008, s. 42). Pod koniec lat 80. XIX wieku została podniesiona do rangi rezydentury i stała się główną siedzibą władz Kompanii na obszarze Zatoki. Stopniowo struktury administracyjne Kompanii zostały włączane do sytemu administracyjnego całego Imperium i pełniły względem niego funkcje służebne. Proces ten uległ przyśpieszeniu z początkiem XIX wieku. W roku 1820 rezydent Kompanii w Busahrze został odpowiedzialny za całość spraw brytyjskich na obszarze Zatoki. Uzyskał oficjalny tytuł rezydenta w Zatoce Perskiej, przy czym zadania przed nim postawione obejmowały nadzorowanie brytyjskich relacji dyplomatycznych i handlowych w całym obszarze Zatoki. W latach 40. rezydent zaczął również sprawować funkcje konsularne. Istotne zmiany politycznym statusie rezydentury nastąpiły w drugiej połowie XIX wieku. Po likwidacji Kompanii Wschodnioindyjskiej nie została ona zniesiona, lecz w pełni włączona w struktury administracyjne Imperium Brytyjskiego. Kolejny etap w jej funkcjonowaniu rozpoczął się w 1873 roku, kiedy zapadły ważne decyzje o charakterze administracyjnym. Rezydentura pod względem administracyjno-kompetencyjnym została podporządkowana brytyjskiemu rządowi Indii (Zahlan, 2002, s. 16). Świadczyło to również o wprowadzonym w Imperium Brytyjskim dualizmie administracyjnym w odniesieniu do Bliskiego Wschodu. Sprawy Zatoki zostały wyjęte spod kompetencji Foreign Office i Colonial Office i przekazane władzom brytyjskim w Indiach. Wynikało to z przyjęcia założenia, że obszar Zatoki Perskiej jest kluczowy dla zabezpieczenia szlaków komunikacyjnych z Indiami, tym samym kluczowe decyzje dotyczące tego obszaru powinny być podejmowane przez brytyjski rząd Indii. Z kolei Rząd imperialny został obarczony odpowiedzialnością za realizację interesów brytyjskich na obszarze Lewantu. Konsekwencją powyższych decyzji było jednak swoiste "pęknięcie” brytyjskiej polityki bliskowschodniej utrzymujące się także w pierwszych dekadach XX wieku.

Wielka wojna z lat 1914-1918 zburzyła wielowiekowy ład polityczny i terytorialny na obszarze Bliskiego Wschodu. Imperium tureckie, które przez pierwsze lata wojny nadspodziewanie skutecznie radziło sobie z prowadzeniem działań wojennych przeciwko wojskom rosyjskim i brytyjskim, ostatecznie skapitulowało w październiku 1918 roku. Dotychczasowe posiadłości bliskowschodnie imperium osmańskiego dostały się pod kontrolę państw ententy, a przede wszystkim 
Wielkiej Brytanii. Traktaty pokojowe z Lozanny i Sèvres przypieczętowały utratę tureckich prowincji bliskowschodnich. W rękach państw ententy znalazły się takie obszary jak Żyzny Półksiężyc. Głównym beneficjentem tej sytuacji stawała się Wielka Brytania, która urosła do roli największego europejskiego mocarstwa kolonialnego na Bliskim Wschodzie. Zdobyte na Turcji terytoria bliskowschodnie zostały przejęte przez Brytyjczyków, jednak nie zostały automatycznie włączone do brytyjskiego systemu imperialnego jako terytoria kolonialne. Odpowiedzialne było za to wiele okoliczności, na które składały się m.in. rozbudzone przy współudziale brytyjskim nastroje nacjonalistyczne w regionie oraz rywalizacja polityczna pomiędzy lokalnymi szejkami, którzy w okresie działań wojennych pozostawali protegowanymi brytyjskimi ${ }^{1}$.

Arabskie dążenia nacjonalistyczne, jak również szersze uwarunkowania międzynarodowe ${ }^{2}$ zdecydowały o tym, że w przypadku byłych posiadłości tureckich wprowadzono quasi-kolonialny system mandatowy. Przy czym Wielka Brytania musiała się podzielić obszarami mandatowymi z Francją. System ten, $\mathrm{z}$ jednym znaczącym wyjątkiem w postaci Iraku, przetrwał okres międzywojenny. Ogłoszenie sprawowania mandatu nad Mezopotamią w 1920 r. spowodowało wybuch antybrytyjskiego powstania, które Imperium Brytyjskie zdołało zdławić $\mathrm{z}$ wielkim trudem. W konsekwencji niepewna sytuacją wewnętrzna w Mezopotamii spowodowała, że Brytyjczycy sięgnęli do rozwiązań politycznych. W 1921 roku doszło do porozumienia z jednym z przywódców antytureckiego powstania z okresu wojny, szejkiem Fajsalem z rodu Haszymidów, ogłoszonego przez Brytyjczyków królem nowego państwa - Iraku³, które do uzyskania niepodległości w 1932 roku formalnie stanowiło terytorium mandatowe Wielkiej Brytanii.

1 Dotyczyło to przede wszystkim rodu Haszymidów i Saudów, którzy rywalizowali ze sobą o kontrolę nad Hidżazem i Nadżdżem.

2 W tym przypadku chodzi o politykę prezydenta Woodrowa Wilsona wobec przyszłości dawnych obszarów tureckich na Bliskim Wschodzie.

3 Koronacja nastąpiła w 1921 roku w Bagdadzie w dość szczególnych okolicznościach. Po ukoronowaniu Fajsala, z braku odpowiedniej pieśni arabskiej, odegrano hymn Imperium Brytyjskiego, Rule Britannia. Trudno o bardziej wymowny symbol zależności nowo kreowanego państwa. Kolejne dziesięciolecie zostało poświecone na stworzenie od podstaw struktur państwowych, które połączyłyby w jeden kraj trzy odrębne prowincje byłego imperium osmańskiego. Przy czym Wielka Brytania zadbała przez ten czas o zabezpieczenie swoich interesów strategicznych i gospodarczych w Iraku. Te ostatnie wiązały się z utworzeniem Iraq Petroleum Company, w którym brytyjska Anglo Persian Oil Company odgrywała kluczową rolę. Ostatecznie Irak uzyskał niepodległość w roku 1932. 
Istotnym wydarzeniem, które w okresie powojennym osłabiało stabilność dominacji brytyjskiej, była rywalizacja pomiędzy królestwem Hidżazu rządzonym przez szarifa Mekki Husajna ibn Alego a sułtanatem Nadżdżu i Hasy Abdul Azizem Ibn Saudem. Sytuację komplikował fakt, że obydwaj władcy formalnie byli brytyjskimi protegowanymi na Półwyspie Arabskim. Brytyjskie próby mediacji pomiędzy byłymi sojusznikami z okresu działań wojennych nie przyniosły rezultatu. Ambicje polityczne obydwu monarchów arabskich doprowadziły do nieuchronnego starcia.

W lecie 1924 roku siły saudyjskie rozpoczęły kampanię wojenną, której celem był ostateczny podbój Hidżazu (Kostiner, 1988, s. 39). Na skutek sukcesów Ibn Sauda jesienią tegoż roku sytuacja militarna Hidżazu była już beznadziejna. Próby uzyskania pomocy brytyjskiej, jakie podjął Husajn, zakończyły się niepowodzeniem. Sytuacji nie uratowała również abdykacja Husajna i przekazanie 6 października 1924 roku tronu Hidżazu jego synowi Alemu (Hewins, 1963, s. 197). Tydzień później wojownicy Sauda wkroczyli do Mekki. Proces podboju Hidżazu został zakończony w grudniu 1925 roku, kiedy Saudowi poddały się Medyna i Dżudda. Po abdykacji Alego notable Mekki uznali Ibn Sauda za nowego króla (Zdanowki, 2004, s. 119). W ten sposób Ibn Saud stawał się ostatecznym zwycięzcą długotrwałego procesu walki o władzę na obszarze Arabii.

Zwycięstwo rodu Saudów oraz konsolidacja pod ich rządami większości terytorium Półwyspu Arabskiego stworzyła nową sytuację polityczną na obszarze Bliskiego Wschodu. Konsekwencje tego wydarzenia nabierały szczególnie ważnego znaczenia dla polityki regionalnej Wielkiej Brytanii. Istotnym elementem reakcji Londynu było dążenie do jak najszybszego uregulowania relacji z nowym tworem politycznym, który powstał w obszarze brytyjskich wpływów. Do zdefiniowania relacji brytyjsko-saudyjskich dążył również Ibn Saud. Po podboju Hidżazu relacje saudyjsko-brytyjskie znalazły się w szczególnej sytuacji. Ibn Saud został nie tylko uznany przez mieszkańców Hidżazu nowym władcą. Również jego władza uzyskiwała stopniowe uznanie międzynarodowe. Co więcej, rządził państwem, które należało do Ligi Narodów. W świetle praktyki prawnomiędzynarodowej jego rządy i państwo, którym rządził, można było uznawać za w pełni suwerenne. Jednakże sytuacja międzynarodowa państwa Sauda była niejasna. Mimo niezaprzeczalnych atrybutów suwerenności, na mocy układu o protektoracie zawartym z Wielką Brytanią w 1915 roku, nowy władca Hidżazu był zobligowany do podporządkowania się w kwestii relacji z zagranicą Imperium Brytyjskiemu. Taki stan rzeczy nie odpowiadał Saudowi i dlatego zabiegał on o zredefiniowanie relacji z Wielką Brytanią. Dążąc do realizacji tego celu, zapro- 
ponował Brytyjczykom podpisanie nowego układu anulującego układ o protektoracie. Po kilku miesiącach wahania Londyn wyraził zgodę na podpisanie stosownego dokumentu. W dniu 20 maja 1927 roku Wielka Brytania i Ibn Saud podpisali traktat w Dżuddzie. Brytyjczycy uznawali w nim Ibn Sauda za suwerennego króla Hidżazu, sułtana Nadżdżu i innych obszarów zależnych (Wilkinson, 1993, s. 152). W zamian Saud godził się na ważną z punktu widzenia Wielkiej Brytanii koncesję polityczną. Zaakceptował on dominującą pozycję brytyjską na obszarze Bliskiego Wschodu i w rejonie Zatoki Perskiej. W podpisanym traktacie zaznaczył, że będzie respektował porozumienia, jakie Wielka Brytania wcześniej zawarła z szejkanatami Zatoki. Zadeklarował również, że nierozwiązane kwestie graniczne $\mathrm{z}$ emiratem Transjordanii zostaną rozstrzygnięte w późniejszym czasie (Zdanowski, 2004, s. 120). Tym samym zostały określone ogólne zręby nowego ładu terytorialnego na obszarze Arabii i w obszarze Zatoki Perskiej. Nie rozstrzygnięto wszystkich kwestii spornych dotyczących przebiegu granic, jednakże istniała nadzieja, że ewentualne ich korekty da się przeprowadzić przy wykorzystaniu środków pokojowych. Przynajmniej Wielka Brytania zyskiwała przekonanie, że nastąpiło wzmocnienie pozycji tych sił regionalnych, które były od niej uzależnione.

Z drugiej jednak strony nie sposób było nie dostrzegać, że w konsekwencji powstawał silny ośrodek polityczny, nominalnie niepodlegający zwierzchnictwu brytyjskiemu4. Z punktu widzenia szejkanatów Zatoki zaistniała sytuacja, w której zobowiązanie Ibn Sauda wyrażające zaakceptowanie istnienia szejkanatów podporządkowanych Wielkiej Brytanii stwarzała stan niepewności. W istocie kwestią ostatecznie nierozstrzygniętą było czy ekspansja państwa saudyjskiego rzeczywiście uległa zakończeniu. W tym względzie istniały dość realne wątpliwości. Chociażby dla Kuwejtu znaczącą kwestią było nałożenie na niego przez Arabię Saudyjską sankcji gospodarczych i rozpoczęcie z nim wojny celnej (Abu-Hakima, 1983, s. 155)5. Nie ustawały również presja militarna w postaci ataków Ichwanów ${ }^{6}$ na emirat (Rush, 1989a, s. 10). Sytuacja ta skłaniała brytyjskich

4 Państwo Sauda otrzymało swoją oficjalną nazwę - Królestwo Arabii Saudyjskiej w roku 1932 r. (Cleveland, 2000, s. 227). Zatem dopiero od tego momentu należałoby posługiwać się nazwą - Arabia Saudyjska. Zdając sobie sprawę z takich okoliczności, mimo pewnej różnicy w czasie autor niniejszego opracowania w dalszej jego części będzie posługiwał się nazwą Arabia Saudyjska, odnosząc ją również do państwa rządzonego przez Ibn Sauda przed rokiem 1932.

5 A.M. Abu-Hakima (1983), The Modern History of Kuwait. 1750-1965, London, s. 155.

6 Plemienne milicje wyznające ideologię wahhabizmu, formalnie uznające zwierzchność rodu Saudów. 
przedstawicieli w Zatoce do konstatacji, iż dążenie do przejęcia Kuwejtu przez Arabię Saudyjską było scenariuszem rozwoju wydarzeń, który należało wziąć pod uwagę (Finnie, 1992, s. 88).

Pod koniec lat 20. dwie okoliczności determinowały stanowisko Wielkiej Brytanii względem relacji z szejkanatami Zatoki. Charakter tych relacji zależał z jednej strony od rozwoju sytuacji politycznej wynikającej z pojawienia się dwóch ośrodków politycznych - Arabii Saudyjskiej i Iraku, który choć w tym czasie był brytyjskim obszarem mandatowym, to w stosunkowo krótkim czasie miał zostać przekształcony w państwo niezależne. Poprawne stosunki z tymi państwami były niezwykle ważne dla Londynu, biorąc pod uwagę stabilność regionalnych wpływów brytyjskich. W takich okolicznościach w Londynie zdawano sobie sprawę z tego, że zarówno Saud, jak i iraccy Haszymidzi, nie w pełni akceptowali niezależność polityczną szejkanatów Zatoki (Assiri, 1990, s. 6). Tym samym brytyjskie zobowiązania polityczne względem nich stanowić mogły potencjalne źródło napięć w relacjach z Arabią Saudyjską i Irakiem. Z drugiej strony okoliczności o szerszym wymiarze również były czynnikiem wpływającym na dążenie Wielkiej Brytanii do szczegółowego określenia charakteru własnej obecności w obszarze Zatoki. Zakończona zwycięstwem nad Niemcami i Turcją wojna przyniosła dominację polityczną Wielkiej Brytanii na Bliskim Wschodzie. Rząd brytyjski mógł zakładać, że zniknęło zewnętrzne zagrożenie dla regionalnej pozycji Wielkiej Brytanii w postaci aktywności mocarstw europejskich takich jak Niemcy czy Rosja.

O ile w przypadku Niemiec sytuacja taka wydawała się trwała, o tyle w przypadku Rosji rzecz miała się zgoła odmiennie. Jeszcze w 1919 roku Rosja bolszewicka zdołała podpisać układ z Iranem, który dawał jej prawo do interwencji militarnej w tym kraju, w razie gdyby jego terytorium miało służyć za bazę dla działań antybolszewickich. Można zatem uznać, że nowi władcy Rosji zrywali w ten sposób rosyjsko-brytyjskie entente cordiale z 1907 roku i zakładali możliwość odnowienia w tym obszarze dawnej rywalizacji politycznej. Takie niebezpieczeństwo przynosiły również wydarzenia z drugiej połowy lat 20., które rozgrywały się na obszarze Persji. Po obaleniu dynastii Kadżarów i ogłoszeniu się nowym szachem przez Rezę Chana Pahlawiego jego rząd poinformował 10 maja 1927 roku przedstawicieli zagranicznych misji dyplomatycznych, że w przeciągu roku zamierza wypowiedzieć umowy kapitulacyjne (Dann, 1988, s. 51). Decyzja ta spowodowała poważne zaniepokojenie Londynu. Na Whitehall obawiano się, że z takiej sytuacji może skorzystać Związek Radziecki i odnowić tradycyjne rosyjskie zainteresowanie Persją i obszarem Zatoki. Aby utrzymać swoje 
wpływy na obszarze Persji, Brytyjczycy zaangażowali się w negocjacje dotyczące podpisania porozumienia o charakterze handlowym. Jego głównym celem było stworzenie warunków, w których rząd perski byłby zainteresowany utrzymaniem korzystnych dla wielkiej Brytanii relacji. Wraz z upływem czasu określonego przez Persów 10 maja 1928 roku został zwarty nowy traktat, w którym Wielka Brytania uznawała suwerenne prawa Persji w zakresie polityki handlowej i wymiaru sprawiedliwości przy jednoczesnym otrzymaniu pewnych przywilejów dotyczących działalności obywateli brytyjskich na terytorium perskim (Dann, 1988, s. 52). Zawarcie układu z Persją oddalało na pewien czas zagrożenie reaktywacją wpływów rosyjskich. Cała sytuacja stanowiła wyraźny sygnał dotyczący konieczności oszacowania zakresu zobowiązań brytyjskich na obszarze Zatoki i wypracowania całościowej koncepcji strategii politycznej i militarnej w tym newralgicznym obszarze dla bezpieczeństwa Imperium Brytyjskiego.

Miesiąc później, 22 maja 1928 roku rząd brytyjski podjął decyzję o powołaniu specjalnego komitetu składającego się z członków gabinetu, którego celem miało być przeanalizowanie polityki brytyjskiej na obszarze Zatoki Perskiej, biorąc pod uwagę aktualną sytuację polityczną. Komitet ten został wkrótce przekształcony w Podkomitet ds. Zatoki Perskiej Komitetu Obrony Imperium (Persian Gulf Sub-Committee of the Committee of Imperial Defence - PGSC) (Zahlan, 2016, s. 145).

Pomimo, że celem prac Podkomitetu było wypracowanie całościowej strategii polityczno-militarnej w obszarze Zatoki Perskiej w instrukcjach przygotowanych na jego użytek podkreślano również konieczność oszacowania skali zaangażowania w poszczególnych protektoratach brytyjskich (Rush, 1989a, s. 25).

Prace Podkomitetu zostały zakończone w październiku 1928 roku. Pod koniec tego miesiąca był gotowy wstępny raport zawierający rekomendacje dotyczące postawionych przed nim celów. Członkowie Podkomitetu uznawali, że brytyjska supremacja w obszarze Zatoki Perskiej jest równie niezbędna dla bezpieczeństwa Indii Brytyjskich i całego Imperium jak w okresie poprzedzającym wielką wojnę. Stwierdzano, iż interesy brytyjskie w tym regionie pozostawały wystawione na stałe zagrożenia, chociaż odmiennej natury niż przed rozpoczęciem działań wojennych. Zwracano uwagę, że pojawiło się nowe zagrożenie dla pozycji brytyjskiej w postaci rozwoju nowego rodzaju broni - sił powietrznych. Raport zakładał, że w celu utrzymania supremacji brytyjskiej w Zatoce niezbędne jest niedopuszczenie do tego, aby jakiekolwiek obce mocarstwo ustanowiło swoją bazę morską bądź ufortyfikowany port nad Zatoką lub też było zdolne do posiadania baz lotniczych w odległości umożliwiającej dokonania ataku przeciwko 
celom znajdującym się w jej obszarze. Raport podkreślał konieczność zapewnienia Royal Navy swobody działań operacyjnych w tej części Bliskiego Wschodu. W odniesieniu do interioru Półwyspu Arabskiego postulowano zachowanie istniejącego status quo. Podkreślano, że pozycja brytyjska u wybrzeży Zatoki wynika z układów, które oddawały pod protekcję brytyjską terytoria tamtejszych szejkanatów. Autorzy raportu jednocześnie wskazywali, że w interesie brytyjskim jest zapewnienie przyjaznych relacji z Ibn Saudem. Tym samym raport Podkomitetu nie sugerował radykalnych zmian w strategii politycznej wobec obszaru Zatoki Perskiej. Wielka Brytania była zdeterminowana utrzymać w tym obszarze swoje wpływy polityczne i militarne za wszelką cenę i nie dopuścić do tego, aby pojawiła się jakakolwiek siła polityczna czy to o charakterze lokalnym, czy też zewnętrznym, zdolna do ich ograniczenia. Należy podkreślić, że w tym kontekście uznano za istotne utrzymanie protektoratu nad szejkanatami Zatoki, a zatem i nad Kuwejtem. Kontrola nad nimi stanowiła ważny element zabezpieczenia swobodnego działania floty brytyjskiej na przyległych akwenach oraz funkcjonowania imperialnych linii komunikacyjnych.

Brytyjskie interesy w obszarze Zatoki w coraz wyraźniejszym stopniu były determinowane przez czynnik o charakterze strategicznym, jakim była ropa naftowa. W wyniku rozwoju technologicznego brytyjskie siły były coraz bardziej uzależnione od dostępu do tego surowca. Odnosiło się to nie tylko do Royal Navy, bez dostępu do ropy trudno było sobie wyobrazić funkcjonowanie RAF. W ten sposób została stworzona sytuacja, w której przedstawiciele sił powietrznych zabierali coraz wyraźniejszy głos w dyskusji nad różnymi wymiarami brytyjskiej polityki bliskowschodniej (Dann, 1988, s. 62).

Raport Podkomitetu trafił pod obrady gabinetu brytyjskiego w dniu 5 listopada 1928 roku i uzyskał jego generalną akceptację. Jednakże w trakcie dyskusji nad raportem uznano, że Podkomitet powinien kontynuować swoje prace i dostarczać dalszych wytycznych dla działań politycznych w rejonie Zatoki Perskiej. Jego dalsze prace trwały do połowy marca 1929 roku. W tym czasie uzewnętrzniły się wyraźne różnice pomiędzy poszczególnymi ministerstwami w kwestii sprawowania nadzoru nad brytyjską polityką względem obszaru Zatoki. Doszło w tym względzie do wyraźnego sporu kompetencyjnego, który był odzwierciedleniem rywalizacji pomiędzy tradycyjnymi i nowymi ministerstwami w rządzie brytyjskim. Kwestia ta była o tyle istotna, że gra również szła o uzyskanie środków finansowych w okresie cięć wydatków na cele obronne w budżecie brytyjskim. W tej rywalizacji po jednej stronie stanął Rząd Indii, Ministerstwo Indii wraz z Royal Navy, drugą zaś stroną rywalizacji stało się 
Ministerstwo Kolonii współdziałające z RAF. W tych okolicznościach można mówić o odnowieniu "tradycyjnego" sporu o kształtowanie i ujednolicenie brytyjskiej polityki wobec Bliskiego Wschodu. Zatem okazało się, że podział kompetencyjny z początku okresu powojennego nie powstrzymał ambicji wielu polityków i wojskowych brytyjskich.

W szczególności marszałek lotnictwa Hugh Trenchard, szef Sztabu Sił Powietrznych, był osobą, która podkreślała konieczność powierzenia RAF zadania zabezpieczenia Pax Britannica zarówno w obszarze Zatoki, jak i na całym Bliskim Wschodzie. W ten sposób nowo powstały rodzaj broni wkraczał w obszar kompetencji przynależnych do tej pory marynarce brytyjskiej. Co więcej, Trenchard postulował całkowite przejęcie przez Ministerstwo Kolonii kontroli nad brytyjską polityką wobec całego Bliskiego Wschodu. W jego opinii brytyjski rząd Indii oraz Ministerstwo Indii powinny skoncentrować swoją działalność wyłącznie na problemach dotyczących samych Indii. Jako uzasadnienie podawał wzrost działalności kręgów nacjonalistycznych i konieczność przeciwdziałania tego typu tendencjom (Dann, 1988, s. 62). W związku z powyższym nie dziwi fakt, że Admiralicja oraz Ministerstwo Indii wspólnie wystąpiły przeciwko koncepcjom Trencharda. Obydwie instytucje rządowe zaproponowały przywrócenie tradycyjnej, pochodzącej sprzed 1921 roku, struktury odpowiedzialności za interesy brytyjskie na obszarze Bliskiego Wschodu. W sytuacji rozowoju rywalizacji na szczeblu ministerialnym brytyjska polityka bliskowschodnia znalazła się w wyraźnym impasie.

Próbą rozwiązania powyższych problemów było powołanie w ramach PGSC kolejnego komitetu ministerialnego. W ten sposób powstał w marcu 1929 roku. Podkomitet ds. Kontroli Politycznej (Subcommittee on Political Control). Zadanie, jakie przed nim postawiono, polegało na „[...] przedstawieniu rekomendacji dotyczącej metod, na podstawie których zostaną uproszczone i przyśpieszone mechanizmy politycznej kontroli na obszarze Arabii” (Rush, 1989c, s. 533). W skład Podkomitetu weszli przedstawiciele ministerstw zainteresowanych powyższymi kwestiami. Na jego czele stanął sekretarz skarbu sir Warren Fisher, stąd określany jest on także jako komitet Fishera (Dann, 1988, s. 63). Komitet w trakcie swojej działalności odbył cztery sesje plenarne pomiędzy 1 maja a 24 października 1929 roku. W tym czasie doszło do przesilenia gabinetowego. Upadł rząd Balwina, a kolejnym premierem został laburzysta Ramsay MacDonald. Sprawy, którymi zajmował się komitet Fishera, były na tyle istotne dla polityki zagranicznej Wielkiej Brytanii, że zawirowania polityczne nie spowodowały przerwania jego prac. Prace i rekomendacje komitetu były tym ważniejsze, 
że odbywały się w czasie, w którym doszło do wzrostu napięcia politycznego na obszarze Arabii spowodowanego buntem Ichwanów przeciwko rządom Ibn Sauda (Zdanowski, 2004, s. 124). Zatem trwający wciąż stan niepewności politycznej na obszarze Arabii był czynnikiem, który podkreślał konieczność wypracowania dalszej strategii politycznej w tym obszarze oraz wyraźnego określenia kompetencji rywalizujących ze sobą departamentów rządowych.

Raport komitetu Fishera został przedstawiony 12 grudnia 1929 roku. Został on podzielony na dwie części. Pierwsza z nich zawierała rekomendacje dotyczące podstawowego zadania postawionego przed komitetem (Rush, 1989c, s. 537). Ta część raportu została zaakceptowana przez wszystkich jego członków. Z kolei druga zawierała propozycję przekazania Foreign Office kierowania całością spraw bliskowschodnich Wielkiej Brytanii. Propozycja ta wykraczała poza podstawową problematykę prac komitetu i nie zyskała aprobaty wszystkich jego członków.

Raport Fishera zwracał uwagę na zaistnienie pogłębiającego się coraz bardziej zaangażowania różnych departamentów rządowych w politykę bliskowschodnią. Wobec wzrastającego stopnia komplikacji spraw politycznych w obszarze zaistniały problemy koordynacji działań departamentów rządowych. Autorzy raportu zauważali, że do tej pory koordynacja taka miała miejsce bądź w oparciu o wymianę korespondencji pomiędzy poszczególnymi departamentami, bądź też poprzez nieformalne konferencje urzędników departamentów zwoływane ad hoc. System ten stracił jednak swoją użyteczność. Jednakże aby przyśpieszyć system podejmowania decyzji i ich implementacji, zaproponowano powołanie dwóch stałych podkomitetów w ramach CID. Pierwszy z nich miał procesować na szczeblu ministerialnym i jego członkami mieli być sekretarze spraw zagranicznych, kolonii, wojny, Indii, sił powietrznych oraz pierwszy lord admiralicji wraz z sekretarzem CID. Z kolei w pracach drugiego mieli uczestniczyć wysocy urzędnicy wymienionych departamentów. Obydwa podkomitety miały podejmować swoje prace na prośbę jednego z departamentów rządowych w razie gdyby rozpatrywano kwestie dotyczące obszaru Bliskiego Wschodu i Zatoki Perskiej. Przy czym sugerowano, aby podkomitet ministerialny zbierał się tylko w sytuacji, gdyby urzędnicy departamentów nie byli w stanie wypracować wspólnego stanowiska. Niektóre istotne sugestie raportu świadczyły o wzroście znaczenia RAF w systemie obronnym Imperium Brytyjskiego. Raport potwierdzał konieczność zabezpieczenia utworzenia lotniczych szlaków komunikacyjnych biegnących przez obszar Bliskiego Wschodu i Zatoki Perskiej w kierunku Indii. W tym względzie brytyjski rezydent polityczny w Zatoce miał ściśle współpracować z przedstawicielem Ministerstwa Sił Powietrznych stacjonującym w Bagdadzie. 
Raport również odzwierciedlał rosnącą rolę obszaru Arabii w polityce brytyjskiej. Autorzy raportu sugerowali bowiem przeniesienie siedziby rezydenta politycznego z Buszahry w Persji na arabskie wybrzeże Zatoki (Rush, 1989c, s. 540).

W drugiej części raportu Komitetu Fishera jego autorzy odnosili się do rywalizacji między departamentami dotyczącej zarządzania polityką bliskowschodnią. Stwierdzano, że w minionych latach istniało wiele konfliktów, które opóźniały podejmowanie decyzji politycznych, a tym samym adekwatną reakcję na zmieniającą się sytuację polityczną na Bliskim Wschodzie. W konsekwencji sugerowano, aby „powierzyć pojedynczemu departamentowi ogólną kontrolę naszych relacji, zarówno administracyjnych, jak i politycznych, na całym terytorium Bliskiego Wschodu, którym jesteśmy zainteresowani, tj. w Sudanie, Egipcie, Palestynie, Transjordanii, Iraku i Arabii (wyłączając być może Aden i takie kwestie szczegółowe związane z administracją, które są w pierwszoplanowym zainteresowaniu rządu Indii) oraz Persji” (Rush, 1989c, s. 542).

Raport Fishera został poddany analizie przez rząd imperialny. Sugestie pierwszej części raportu zostały w większości zaakceptowane. Na początku lat 30. powołano do życia dwa stałe podkomitety wewnątrz CID mające zajmować się problematyką dotyczącą Bliskiego Wschodu (Dann, 1988, s. 67). W odniesieniu do kwestii przeniesienia rezydentury politycznej na wybrzeże arabskie, rząd odłożył podjęcie decyzji w tej sprawie. Ostatecznie pomysł ten został porzucony. Podobnie rzecz miała się z rekomendacjami drugiej części raportu. Zgodnie z jej sugestiami zaakceptowano przekazanie spraw dotyczących Iraku z Ministerstwa Kolonii do Foreign Office. Było to wynikiem mającego wkrótce nastąpić przekształcenia terytorium mandatowego w niezależne państwo.

\section{PODSUMOWANIE}

Biorąc pod uwagę prace PGSC oraz komitetu Fishera, należy stwierdzić, że na przełomie lat 20. i 30. XX wieku ostatecznie wypracowano procesy decyzyjne w Wielkiej Brytanii dotyczące obszaru Bliskiego Wschodu w tym Zatoki Perskiej. Rząd brytyjski uznawała, że rejon Zatoki Perskiej stanowi jeden z kluczowych obszarów strategicznych, którego kontrola jest niezwykle istotna dla bezpieczeństwa całego Imperium. Powyższe założenie zostało zdeterminowane przez dwa rodzaje okoliczności. Po pierwsze, należy zaznaczyć, że brytyjskie siły zbrojne, a przede wszystkim flota i lotnictwo, z przyczyn technicznych były uzależnione od ropy naftowej. W obszarze Zatoki Perskiej znajdowały się znaczne zasoby tego 
surowca. Z tego względu należało zapewnić swobodny dostęp do źródeł ropy naftowej, przede wszystkim firmom brytyjskim, co miało również istotny wpływ na rozwój gospodarki i stan finansów Zjednoczonego Królestwa. Wreszcie rola obszaru Bliskiego Wschodu i Zatoki Perskiej, jako ważnego terytorium tranzytowego Imperium, jeszcze bardziej wzrosła po zakończeniu I wojny światowej. Bliski Wschód stawał się obszarem, nad którym kontrola była ważna nie tylko dla admiralicji, ale również dla Ministerstwa Sił Powietrznych, które konsekwentnie twierdziło, że Zatoka jest dla niego tym samym, czym Kanał Sueski dla admiralicji (Al-Roumi, 1980). Plany brytyjskie obejmowały poprowadzenie powietrznych szlaków komunikacyjnych wzdłuż arabskich wybrzeży Zatoki Perskiej (Burrows, 1990, s. 16). Z tego też powodu zachowanie kontroli politycznej nad szejkanatami Zatoki nabierało żywotnego znaczenia dla Wielkiej Brytanii. Kolejne gabinety brytyjskie były stale zainteresowane utrzymaniem istniejącego status quo pod względem politycznym i terytorialnym. $\mathrm{W}$ interesie brytyjskim nie leżało, aby szejkanaty Zatoki, w tym Kuwejt, znalazły się pod kontrolą Arabii Saudyjskiej lub już wkrótce niepodległego Iraku. Tym samym kolejne działania brytyjskie miały iść w kierunku utrzymania zależności poszczególnych szejkanatów od Wielkiej Brytanii i niedopuszczenie do tego, aby zostały wchłonięte przez większych i potężniejszych sąsiadów (Rush, 1989b, s. 380). Jednakże ze względów praktycznych HMG zakładał sprawowanie kontroli nad szejkanatami przy zastosowaniu możliwie ograniczonych środków. Brytyjczycy nie przewidywali zaangażowania się w bezpośrednie zarządzanie sprawami wewnętrznymi podległych im szejkanatów. Był to raczej system, który można określić mianem „nieformalnego imperium” lub „imperium traktatowego". Brytyjczycy przyjęli politykę ograniczonego wpływu. Nie ingerowano w sprawy wewnętrzne poszczególnych szejkanatów tak długo, jak rozwój sytuacji wewnętrznej nie stwarzał zagrożenia dla brytyjskich interesów politycznych (Zahlan, 1989, s. 22). W kolejnych dziesięcioleciach powyższe zasady zostały w pełni zastosowane wobec zależnych od Imperium Brytyjskiego szejkanatów Zatoki. Sytuacja ta przetrwała do końca lat 40., kiedy to konsekwencje II wojny światowej wymusiły kolejną redefinicję podstaw brytyjskiej polityki wobec Bliskiego Wschodu i subregionu Zatoki Perskiej. 
BibLIOGRAFIA:

Abu-Hakima, A.M. (1983). The Modern History of Kuwait. 1750-1965. London: Luzac and Co Ltd.

Assiri, A.R. (1990). Kuwait's Foreign Policy. City-State in World Politics. Boulder-San Francisco-London: Westview Press.

Burrows, B. (1990). Footnotes in the Sand: The Gulf in Transition, 1953-1958. Salisbury: Michael Russell.

Cleveland, W.L. (2000). A History of the Modern Middle East. Oxford: Westview Press.

Dann, U. (1988). British Persian Gulf Concepts in the Light of Emerging Nationalism in the Late 1920s. W: U. Dann (red.), The Great Powers in the Middle East 1919-1939. New York-London: Holms and Meier.

Finnie, D.H. (1992). Shifting Lines in the Sand. Kuwait's Elusive Frontier with Iraq. Cambridge Mass.: Harvard University Press.

Hewins, R. (1963). A Golden Dream. The Miracle of Kuwait. London: W.H. Allen.

Hurewitz, J.C. (1956). Diplomacy in the Near and Middle East. A Documentary Record, 1, 1535-1914. Princeton-New Jersey-Toronto-New York-London: Van Nostrand.

Kostiner, J. (1988). Britain and the Northern Frontier of the Saudi State, 1922-1925. W: U. Dann (red.), The Great Powers and the Middle East 1919-1939. New York-London: Holms and Meier.

Roumi, M. Al (1980). Kuwait and Malta: British Imperial Policy 1899-1939. Malta: University of Malta.

Rush, A. de L (red.). (1989a). Records of Kuwait 1899-1961. Internal Affairs 1921-1950, 2.

Rush, A. de L (red.). (1989b). Records of Kuwait 1899-1961. Foreign Affairs, 6.

Rush, A. de L (red.). (1989c). Records of Kuwait 1899-1961. Foreign Affairs II, 7.

Wilkinson, J.C. (1993). Arabia's Frontiers: The Story of Britain's Boundary Drawing in the Desert. London-New York: I.B. Tauris.

Zahlan, R.S. (1998). The Making of the Gulf States. Kuwait, Bahrain, Qatar, the United Arab Emirates and Oman. London: Garnet.

Zahlan, R.S. (2016). The Origins of the United Arabs Emirates. A Political and History of the Trucial States. London: Routledge.

Zdanowski, J. (2004). Historia Arabii Wschodniej. Wrocław-Warszawa-Kraków: Ossolineum.

Zdanowski, J. (2008). Slavery in the Gulf in the First Half of the 20 $0^{\text {th }}$ Century. A study Based on the Records from the British Archives. Warszawa: Wydawnictwo Naukowe Askon. 